\title{
Passage Rates, Rumen Fermentation, and Weight Change in Protein Supplemented Grazing Cattle
}

\author{
M.B. JUDKINS, J.D. WALLACE, M.L. GALYEAN, L.J. KRYSL, AND E.E. PARKER
}

\section{Abstract}

Protein supplementation is widely used to enhance the nutritional status of cattle on rangeland. The effects of protein supplementation on particulate and fluid passage rates, rumen fermentation, and weight gain were evaluated on cattle grazing dormant blue grama rangeland. Twelve rumen-cannulated steers were randomly allotted to 3 equal supplement groups (4/treatment): cottonseed cake (CSC), pelleted alfalfa (ALF), or no supplement (CON). Supplements were individually fed every other day at isonitrogenous levels (1.7 kg/hd CSC vs $3.6 \mathrm{~kg} / \mathrm{hd} \mathrm{ALF).} \mathrm{Particu-}$ late passage rate was measured during 2 collection periods. Concurrently, 102 yearling heifers were allotted to the same treatment groups for measurement of average daily gain. Cattle were fed these treatments from January through April 1983. In a second trial, 9 rumen-cannulated steers were randomly allotted to the same treatment groups as trial 1. An intraruminal dose of CoEDTA was used to estimate fluid passage rates. Rumen ammonia, volatile fatty acids, and pH were also measured. In trial 1, average daily gain did not differ between ALF and CSC supplemented heifers; however, both ALF and CSC gained more than CON heifers. Passage rate estimates were not different among treatment groups. In trial 2, rumen fluid dilution rate, volume, and outflow rate were not different among treatments. Rumen ammonia-N was different at $11 \mathrm{~h}$ postsupplementation when the CSC steers had higher levels than steers in other treatment groups. Rumen pH was not influenced by supplementation. Molar proportions of acetate and propionate at 8 and $11 \mathrm{~h}$ after supplementation differed among treatment groups. Acetate was lowest in ALF, intermediate in CSC, and highest in CON supplemented steers. Propionate followed the reverse trend. Overall, protein supplementation improved livestock performance but the mechanism involved was not elicited. The current data suggest shifts in fermentation patterns and meeting dietary demands for gain are the factors involved in improving performance.

Key Words: nitrogen supplementation, rumen fermentation, passage rates, volatile fatty acids, ammonia nitrogen

Improving nutritional status of livestock on rangelands often requires supplemental feeding. Declines in crude protein and available nitrogen content of mature and senescent vegetation result in a need for supplemental protein (Allden 1981, McCollum and Galyean 1985). Although protein supplementation has improved performance of beef cows grazing dormant range (Speth et al. 1962, Parker et al. 1974, Bellido et al. 1981, Clanton 1982), these improvements may not result from increased intake (Rittenhouse et al. 1970, Forero et al. 1980).

Increased voluntary intake of low-quality forages with supplementation is believed to result from increased rate of digestion and(or) passage (Ellis 1978). Gut fill is considered the most limiting factor for intake of forage diets (Campling 1970, Freer 1981). Alteration of rate of passage and(or) digestion may alleviate or potentiate fill effects. Moreover, ruminal escape of supplemental protein may enhance voluntary intake of dormant forage through metabolic effects (Egan 1965, Kempton et al. 1977).

The influence of protein supplementation on fermentation patterns of grazing cattle has not been extensively investigated. Topps

\footnotetext{
At the time of the study authors were graduate assistant, professor, and associate professor, graduate assistant and assistant professor, respectively. Department of Animal and Range Sciences, New Mexico State University, Las Cruces 88003

Submitted as New Mexico Agr. Exp. Sta. Journal Article 1203.

Manuscript accepted 8 September 1986.
}

et al. (1965) and Wagner et al. (1983) found no differences in VFA proportions as a result of protein supplementation in cattle grazing dormant rangelands. However, McCollum and Galyean (1985) noted a shift toward higher propionate with protein supplementation of low-quality prairie hay. The overall objective of this study was to evaluate the effects of protein supplementation and type of supplement (roughage vs concentrate) on livestock performance, passage rates and fermentation patterns. Specifically, this study evaluated the effects of cottonseed meal cake and ground, pelleted alfalfa hay or long-stem alfalfa hay supplements on average daily gain of heifers, digesta and fluid passage rates, and rumen $\mathrm{pH}$, ammonia and volatile fatty acid concentrations in steers grazing dormant blue grama rangeland.

\section{Study Area}

Experiments were conducted at the Fort Stanton Experimental Ranch, a mountain-foothill region in south-central New Mexico. The study area consisted of blue grama (Bouteloua gracilis) rangeland typical of the Southwest. Climate is mild, with cool winters and warm summers. The 78-yr average annual precipitation is 348 $\mathrm{mm}$, of which approximately $55 \%$ occurs from July to September. Mean precipitation for January through May is $83.9 \mathrm{~mm}$. Pasture size, topography, and vegetative composition have been previously described (Judkins et al. 1985).

\section{Methods}

\section{Trial 1}

In January 1983, 9 esophageal- and 12 rumen-cannulated steers (average weight of $230 \mathrm{~kg}$ ) were randomly allotted to 1 of 3 treatments ( 3 esophageal- and 4 rumen-cannulated steers/treatment): control (no supplemental feed [CON]), mechanically extracted cottonseed meal cake $(1.7 \mathrm{~kg} / \mathrm{hd}$ [CSC]) and ground, pelleted alfalfa hay $(3.6 \mathrm{~kg} /$ hd $[\mathrm{ALF}]$ ) (Table 1). Supplements were individually fed at specified amounts (isonitrogenous) every other day from January to May, 1983. Chemical analyses and composition of the diet selected did not differ between treatments (Judkins et al. 1985). All steers were herded to a central location on supplementation days at $0800 \mathrm{~h}$. Control steers were withheld from grazing while supplemented steers were tethered and fed. Following supplement feeding, steers were released to resume grazing. A saltmineral mix ( $50 \%$ dicalcium phosphate, $45 \%$ salt and $5 \%$ cottonseed meal) was provided free choice in the pasture.

Esophageal collections were conducted for 3 consecutive days in 2 periods (mid-February and late March). Esophageal extrusa, composited across steers in a treatment, was used for rate of passage determination.

Particulate rate of passage was measured with rumen-cannulated steers. On day 1, at supplement feeding, ytterbium (Yb)-labeled forage was placed in the rumen (mid-dorsal to mid-ventral region) of each steer via the rumen cannula. Forage had been labeled with $\mathrm{Yb}$ by the immersion and washing procedure described by Teeter et al. (1984). Steers received 95.0, 117.1, and 107.8 g(CON, ALF and CSC, respectively) in February and $90.5,101.5$, and $100.6 \mathrm{~g}(\mathrm{CON}$, ALF, and CSC, respectively) in March of Yb-labeled esophageal forage (dry matter basis). Dose sizes differed due to inevitable dry matter loses during the labeling procedure. Ytterbium content of the labeled forage was $20.7,19.0$, and $21.1 \mathrm{mg} \mathrm{Yb} / \mathrm{g}$ dry matter (CON, CSC, and ALF, respectively) in February and 23.9, 26.0, and $22.6 \mathrm{mg} \mathrm{Yb} / \mathrm{g}$ dry matter (CON, CSC, and ALF, respectively) 
Table 1. Organic matter, nitrogen and fiber components of esophageal fistula samples, cottonseed cake (CSC) and pelleted alfalia bay (ALF) supplements for steers graxing blue grama rangeland.

\begin{tabular}{|c|c|c|c|c|c|c|}
\hline \multirow[b]{2}{*}{ Item } & \multicolumn{3}{|c|}{ Forage diets ${ }^{2}$} & \multicolumn{3}{|c|}{ Supplements } \\
\hline & Feb. 1983 & March 1983 & Jan. 1984 & Trial 1 and $2 \mathrm{CSC}$ & Trial 1 ALF & Trial 2 ALF \\
\hline \multicolumn{7}{|l|}{ Organic matter } \\
\hline Organic matter & 82.6 & 79.3 & 87.1 & 91.5 & 89.0 & 88.6 \\
\hline Crude protein ${ }^{b}$ & 10.4 & 12.6 & 7.7 & 47.7 & 23.0 & 16.4 \\
\hline Soluble nitrogen ${ }^{b}$ & .42 & .50 & .30 & .85 & 1.40 & .91 \\
\hline Insoluble available nitrogen ${ }^{b}$ & .86 & .79 & .50 & 6.50 & 2.20 & 1.59 \\
\hline Insoluble unavailable nitrogen ${ }^{b}$ & .40 & .73 & .45 & .31 & .15 & .12 \\
\hline Neutral detergent fiber ${ }^{b}$ & 80.7 & 78.0 & 87.4 & 21.9 & 42.1 & 44.3 \\
\hline Acid detergent fiber ${ }^{b}$ & 62.3 & 65.4 & 52.7 & 16.2 & 30.1 & 34.2 \\
\hline Acid detergent lignin ${ }^{b}$ & 9.3 & 10.7 & 10.9 & 6.5 & 6.7 & 7.2 \\
\hline
\end{tabular}

"Judkins et al. (1985).

bercentage of organic matter.

in March.

Rectal grab samples were taken at $0,4,8,12,20,24,28,32,36$, $42,48,56,60,72,80,96,104$, and $120 \mathrm{~h}$ postdosing. Actual times were recorded and used in compartmental modeling analysis. However, 1 deviation from the above sampling schedulc occurred. In March, a snow storm ( $50.0 \mathrm{~cm}$ of snow) prevented sampling after $96 \mathrm{~h}$ postdosing.

Fecal samples were prepared for $\mathrm{Yb}$ analysis by drying at $50^{\circ} \mathrm{C}$ for $24 \mathrm{~h}$. Samples were ground through a $2-\mathrm{mm}$ screen and approximately 2-g subsamples were ashed at $550^{\circ} \mathrm{C}$. Ash was solubilized by boiling in $3.1 \mathrm{~N} \mathrm{HCl}$, filtered through ashless (Whatman \#541) filter paper and brought to $50 \mathrm{ml}$ volume with deionized water. Standards for $\mathrm{Yb}$ analysis were made in solubilized ash from $\mathbf{0 ~ h}$ collections. All samples and standards contained $2,000 \mu \mathrm{g} / \mathrm{ml}$ of $\mathrm{K}$ as an ionization buffer. Ytterbium content was determined by atomic absorption spectroscopy using a nitrous oxide/air-acetylene flame.

Fecal $\mathrm{Yb}$ excretion curves were evaluated with a one-compartment model when the data sets failed to fit a two-compartment model (Pond et al. 1982). Curve fitting was accomplished using the nonlinear regression option (Marquardt method) of the Statistical Analysis System (SAS 1982). The equation for the one-compartment model is:

$$
Y=k_{0} \cdot(t-t a u) \cdot\left(k_{1}\right)^{2} \cdot e^{-k_{1} 1^{(t-t a u)}}
$$

$Y=$ marker concentration in feces

$\mathrm{k}_{\mathrm{a}}=$ initial marker concentration

$\mathrm{t} \quad=$ time postdosing

$k_{1}=$ time dependent rate constant

tau = time from dose until first appearance of marker in feces Computation of passage rate, gut fill, intestinal transit time and total mean retention time are:

Flow, $\% / \mathrm{hr}=\left(\mathrm{k}_{1} \times .59635\right) \times 100$

Undigested dry matter fill $=$ dose $/ \mathbf{k}_{\mathbf{o}} \times \mathrm{k}_{1} \times .59635$

Total mean retention time in the gastrointestinal tract, $h r=2 / k_{1}+$ tau Intestinal transit time $=$ tau

Rate of passage data were analyzed as a split-plot design. Supplementation (mainplot) was tested against steer within treatment as an error term. Sampling period and interaction of supplementation $X$ sampling period were tested against residual error.

Intake was determined on rumen-cannulated steers concurrently with passage rate measures and has been previously described and reported by Judkins et al. (1984). Briefly, total fecal collections were conducted for 5 consecutive days. Bags were replaced every 12 hours and combined into 24-hour collections for each steer. Feces were weighed, mixed, and a subsample of $500 \mathrm{~g}$ obtained. Organic matter intake was estimated using fecal organic matter output and diet in vitro organic matter indigestibility from two-stage in vitro digestion. Statistical analysis followed the same procedure as rate of passage parameters.
Animal performance was evaluated using 102 yearling, crossbred Angus $\times$ Hereford heifers (average initial weight of $242 \mathrm{~kg}$ ). Heifers were randomly allotted to the same treatment groups as the cannulated steers, except long-stem alfalfa hay was fed rather than pelleted alfalfa. Supplements were fed every other day from 12 January 1983 to 29 April 1983 (107 d on feed). Heifers were weighed at the beginning and end of the trial and average daily gain during this time period was analyzed as a completely randomized design using initial weight as a covariate in the analysis of variance. Supplementation was the only independent variable in the analysis of variance. The least significant difference procedure was used to compare means when a significant $F$ test was observed (Steel and Torrie 1980).

\section{Trial 2}

In January 1984, rumen-cannulated steers (average weight of $340 \mathrm{~kg}$ ) were randomly allotted to the same treatments as in Trial 1. The alfalfa supplement differed slightly in composition from that used in Trial 1, such that the ALF group received $4.3 \mathrm{~kg} / \mathrm{hd}$ of ground, pelleted alfalfa. Cottonseed cake was the same as fed in Trial 1. Supplements were fed individually every other day for a 5-d adjustment period. All steers had been grazing the pasture for 2 weeks before supplementation. Chemical composition of supplements and the diet selected by esophageal-fistulated steers is shown in Table 1. Esophageal samples were collected from 3 unsupplemented steers on 3 consecutive days. Esophageal-fistulated steers were unsupplemented because previous work indicated no difference in diet selected (Judkins et al. 1985) between supplemented and unsupplemented steers. On supplementation days at $0800 \mathrm{~h}$, steers were tethered where they grazed and fed, while control steers were restricted from grazing.

On the third supplementation day, an intraruminal dose of 200 $\mathrm{ml}$ Co-EDTA containing $499.4 \mathrm{mg}$ Co was administered immediately after feeding to estimate fluid dilution rates (Uden et al. 1980). Rumen samples $(250 \mathrm{ml})$ were collected prior to dosing $(0 \mathrm{~h})$ and at $4,8,11$, and $24 \mathrm{~h}$ thereafter. For each rumen sample, $\mathrm{pH}$ was determined with a combination electrode immediately after removal. Samples were strained through 4 layers of cheesecloth, acidified with $1 \mathrm{ml}$ of $7.2 \mathrm{~N} \mathrm{H}_{2} \mathrm{SO}_{4} / 100 \mathrm{ml}$ of strained fluid and frozen in plastic bags.

In the laboratory, rumen samples were thawed at room temperature and centrifuged at $10,000 \times \mathrm{g}$ for $10 \mathrm{~min}$. The spernatant fraction was analyzed for ammonia by the phenol-hypochlorite procedure of Broderick and Kang (1980) and for Co by atomic absorption spectroscopy with an air/acetylene flame. After an additional centrifugation at $10,000 \times \mathrm{g}$ with addition of an internal standard, volatile fatty acid concentrations were analyzed by gas chromatography as described by Goetsch and Galyean (1983).

Rumen fluid dilution rate was calculated by regressing the natural logarithm of Co concentration on time postdosing (0-h sample not included). Fluid volume was estimated by dividing the dose by the extrapolated concentration at $0 \mathrm{~h}$. Turnover rate was calcu- 
lated by multiplying rumen volume by the fractional equivalent of dilution rate.

Data for Trial 2 were analyzed within time of sampling as a completely randomized design with the main effect of treatment. The least significance difference procedure was used to compare means when a significant $F$ value was obtained from the analysis of variance (Steele and Torrie 1980).

\section{Results and Discussion}

\section{Trial 1}

Initial weight of heifers (Table 2 ) did not differ $(P>.10)$ among treatments; however, supplementation increased $(P<.001)$ average

Table 2. Least square means and standard errors for initial weight, final weight, and average daily gain of heifers supplemented with long-stem alfalia hay (ALF), cottonseed cake (CSC) or no supplement (CON) while graxing blue grama rangeland.

\begin{tabular}{|c|c|c|c|c|}
\hline \multirow[b]{2}{*}{ Item } & \multicolumn{3}{|c|}{ Treatment } & \multirow[b]{2}{*}{$S E^{*}$} \\
\hline & ALF & CSC & CON & \\
\hline $\begin{array}{l}\text { Initial weight, } \mathrm{kg} \\
\text { Final weight, } \mathrm{kg} \\
\text { Average daily gain, } \mathrm{kg} / \mathrm{d} \\
\text { Animals/treatment }\end{array}$ & $\begin{array}{l}239.9 \\
264.5^{b} \\
.23^{b} \\
34\end{array}$ & $\begin{array}{l}242.9 \\
268.8^{\mathrm{b}} \\
.24^{\mathrm{b}} \\
34^{-}\end{array}$ & $\begin{array}{l}242.8 \\
240.0^{c} \\
-.03^{c} \\
34\end{array}$ & $\begin{array}{l}5.7 \\
6.0 \\
.02\end{array}$ \\
\hline
\end{tabular}

"Standard error of least squares means.

b,c Row means with different superscripts differ $(P<.001)$

daily gains (ADG) and final weights. Although both supplemented groups gained weight, heifers receiving no supplemental feed lost weight $(\mathrm{ADG}=-.03 \mathrm{~kg} / \mathrm{d})$. Daily gain did not differ $(P>.10)$ between supplemented heifers $(A L F=.23 \mathrm{~kg} / \mathrm{d}$ vs $C S C=.24 \mathrm{~kg} / \mathrm{d})$. These results agree with work of others at Fort Stanton Experimental Ranch using cottonseed cake (Parker et al. 1974), as well as work by others comparing oilseed meal cakes and alfalfa supplements (Clanton 1982, Smith 1981).

The interaction of supplementation $X$ sampling date was not significant for intake, passage rate, and fill estimates (Table 3). Forage intake of rumen-cannulated steers based on total fecal collections was not influenced by supplementation (Judkins et al. 1985). Total intake was higher $(P<.05)$ in ALF steers than in CSC steers, which were higher than CON steers. Because forage intake did not differ among treatments, increases in total intake reflect addition of supplements rather than associative effects.

Passage rate estimates were not influenced $(P>.10)$ by supplementation. However, passage rate tended to be faster in steers fed ALF (greater total intake), than in steers fed CSC or CON. Moreover, total mean retention time was shorter $(P<10)$ for ALF than for CSC or CON steers. The significant positive association between voluntary intake and particulate passage rate reported by others (Campling et al. 1962, Minson 1966, and McCollum and
Galyean 1985) was not noted in this study, but the current data resembled previous reports on supplementation effects. The absence of a significant supplementation effect on passage rate and forage intake may have resulted from a small number of steers and(or) experimental error. Previous work using identical experimental numbers detected significant treatment effects (McCollum and Galyean 1985).

Between sampling dates, however, passage rate and voluntary intake were not positively related. Passage rates were more rapid and total mean retention times shorter $(P>.05)$ in March (3.91 $\% / \mathrm{h}, 49.4 \mathrm{~h})$ than February $(3.43 \% / \mathrm{h}, 53.3 \mathrm{~h})$, while total intake tended to be lower in April than in February. Other factors such as gut fill (Ellis 1978) and particle size (Troelsen and Campbell 1968) can influence the relationship between passage rate and intake, which may be the case in sampling period results from the present study.

Previously reported data on diet composition (Judkins et al. $1985)$ showed increases in dietary forb content $(68.2 \%$ to $78.8 \%$ forbs, February to March, respectively) caused a rise in dietary crude protein, soluble nitrogen and digestibility. Legume-type forages (i.e., forbs) tend to fragment easily during comminution and to pack more densely in the digestive tract, thereby increasing gut fill (Troelsen and Campbell 1968). Additionally, forbs have a more rapid rate of digestion and increased passage compared with grasses (Kothmann 1980, Poppi et al. 1980). The increases noted in particulate passage rate and gut fill between February and March may reflect dietary shifts in grasses and forbs.

The reason for the discrepancies between increasing particulate passage and slightly lower intake is not apparent. Many factors may have been involved. However, the occurrence of a snow storm $(50.0 \mathrm{~cm}$ snow) at approximately $60 \mathrm{~h}$ postdosing and early termination of fecal sampling $(96 \mathrm{~h})$ may have led to overestimation of particulate passage compared with actual values. Conversely, behavioral changes, including increases in time spent grazing, have been associated with approaching weather fronts (Smith and Malechek 1974). Both of these situations will result in conditions which cause fluctuations in passage rate. Marker-based estimates of particulate movement may be erroneous under changing intake conditions (Morgan et al. 1976), thus, rate of passage results may be environmentally related.

\section{Trial 2}

Rumen ammonia was not different $(P>.10)$ except at 11 h postsupplementation when the CSC ammonia levels were higher $(P<$.05) than ALF or CON levels (Table 4). At supplementation (0 h), rumen ammonia levels were similar for all 3 groups; however, at $4 \mathrm{~h}$ post-supplementation, a slight increase was noted in the 2 supplemented groups. Rumen ammonia during all time periods except at $4 \mathrm{~h}$ for CSC steers was below the $5 \mathrm{mg} / 100 \mathrm{ml}$ requirement suggested by Satter and Slyter (1974) as optimum for microbial protein synthesis. Forage available crude protein level $[4.9 \%$,

Table 3. Total and forage intake, particulate passage rate, rumen retention time and intestinal transit time of steers supplemented with ground pelleted alfalfa (ALF) cottonseed cake (CSC) or no supplement (CON) while grazing blue grama rangeland.

\begin{tabular}{|c|c|c|c|c|c|c|c|}
\hline \multirow[b]{2}{*}{ Item } & \multicolumn{4}{|c|}{ Treatment } & \multicolumn{3}{|c|}{ Sampling period } \\
\hline & ALF & CSC & CON & $S E^{2}$ & February & March & $S E^{\mathbf{a}}$ \\
\hline Steer weight, kg & 274 & 246 & 249 & - & 251 & 263 & - \\
\hline Forage intake, $\mathrm{g} / \mathrm{kg}$ body weight ${ }^{\mathrm{b}}$ & 7.7 & 9.6 & 10.8 & 1.1 & 9.8 & 8.9 & .44 \\
\hline Total intake, $\mathrm{g} / \mathrm{kg}$ body weight ${ }^{\mathrm{b}}$ & $14.1^{\mathrm{c}}$ & $12.9^{d}$ & $10.8^{\circ}$ & .60 & 13.1 & 12.1 & .46 \\
\hline Particulate passage rate, $\% / \mathrm{h}$ & 4.29 & 3.35 & 3.36 & .32 & $3.43^{\mathrm{c}}$ & $3.91^{d}$ & .13 \\
\hline \multicolumn{8}{|l|}{ Gastroinestinal dry matter fill, $\mathbf{g} / \mathbf{k g}$} \\
\hline body weight & 11.2 & 12.8 & 12.7 & 1.4 & 11.9 & 12.5 & .4 \\
\hline Total mean retention time, $h$ & 45.8 & 54.8 & 53.4 & 2.75 & $53.3^{c}$ & $49.4^{d}$ & 1.2 \\
\hline Intestinal transit time, $\mathrm{h}$ & 17.2 & 18.0 & 16.8 & 1.64 & 17.3 & 17.4 & .6 \\
\hline
\end{tabular}

\footnotetext{
Standard error of the mean, $n=4$.

Organic matter basis (previously reported, Judkins et al. 1985).

${ }^{d e}$ Row means with different superscripts differ $(P<.05)$
} 
Table 4. Rumen ammonia and pH of steers grazing blue grama rangeland and receiving either alfalfa pellets (ALF), cottonseed cake (CSC) or no supplemental feed (CON), Trial 2.

\begin{tabular}{|c|c|c|c|c|c|c|c|c|}
\hline \multirow{2}{*}{$\begin{array}{l}\text { Time post- } \\
\text { supplementation }\end{array}$} & \multicolumn{4}{|c|}{ Ammonia $(\mathrm{mg} / 100 \mathrm{ml})$} & \multicolumn{4}{|c|}{ pH } \\
\hline & ALF & CSC & CON & $\mathrm{SE}^{\mathrm{a}}$ & ALF & $\csc$ & $\mathrm{CON}$ & $\mathrm{SE}^{\mathrm{a}}$ \\
\hline $\mathbf{0}$ & 2.9 & 2.0 & 1.5 & .78 & 6.7 & 6.4 & 6.3 & .19 \\
\hline 4 & 3.7 & 6.1 & 1.3 & 3.33 & 5.8 & 6.0 & 6.0 & .21 \\
\hline 8 & 1.4 & 4.1 & 1.4 & 1.27 & 5.9 & 6.2 & 6.2 & .20 \\
\hline 11 & $0.9^{\mathrm{b}}$ & $2.9^{\mathrm{c}}$ & $1.3^{\mathrm{b}}$ & .43 & 5.8 & 6.1 & 6.1 & .18 \\
\hline 24 & 2.8 & 3.6 & 1.6 & .95 & 6.4 & 6.2 & 6.2 & .20 \\
\hline
\end{tabular}

"Standard error of the mean, $n=3$.

${ }^{b}$ Row means with different superscripts differ $(P<.05)$

(total $\mathrm{N}$ - sinoluble unavailable $\mathrm{N}$ ) $\times 6.25$ ] supports the low rumen ammonia concentrations observed in this study. Kellaway and Leibholz (1983) attributed low rumen ammonia concentrations to low rates of production or high rates of utilization. As a result, studies evaluating ammonia concentration and in situ fiber digestion have had mixed results (Mehrez et al. 1977, Grummer et al. 1984).

The absence of a consistent ammonia- $\mathrm{N}$ response due to supplementation contrasts sharply with results of others. Wagner et al. (1983) and McCollum and Galyean (1985) noted higher rumen ammonia- $\mathrm{N}$ levels in protein-supplemented steers. McCollum and Galyean (1985) noted peak concentrations $1 \mathrm{~h}$ after supplementation. In the current study a slight trend was noted for CSC and ALF rumen ammonia levels to increase between 0 and $4 \mathrm{~h}$ after supplementation. Therefore, it is likely that peak ammonia levels were not detected by the sampling scheme utilized in our study.

Rumen $\mathrm{pH}$ was not influenced $(P>.10)$ by supplementation (Table 4), but tended to decline after supplementation in all treatment groups. Wagner et al. (1983) and McCollum and Galyean (1985) also found no differences in rumen $\mathrm{pH}$ as a result of protein supplementation. Addition of finely ground roughages and(or) concentrate feeds has been noted to reduce ruminal pH (Van Soest 1982). The current data and data by others (Wagner et al. 1983, McCollum and Galyean 1985) indicate no decrease in $\mathrm{pH}$ from addition of cottonseed meal or ground alfalfa. Values in this study ranged from a low of 5.8 to a high of 6.7. Mertens (1977) suggested that fiber digestion is inhibited at a $\mathrm{pH}$ lower than 6.7. If this supposition is correct, the effects of $\mathrm{pH}$ on fiber digestion and subsequent utilization needs to be further evaluated.

Rumen fluid dilution rate, volume, and turnover rate were not different $(P>10)$ between treatment groups (Table 5). Dilution

Table 5. Rumen fluid, dilution rate, volume and outflow in steers grazing blue grama rangeland receiving either alfalfa pellets (ALF), cottonseed cake (CSC) or no supplemental feed (CON).

\begin{tabular}{lcccc}
\hline \hline & \multicolumn{4}{c}{ Treatment } \\
\cline { 2 - 5 } Item & $\mathrm{ALF}$ & $\mathrm{CSC}$ & $\mathrm{CON}$ & $\mathrm{SE}^{\mathrm{a}}$ \\
\hline Dilution rate, $\% / \mathrm{h}$ & 6.93 & 7.13 & 7.29 & 1.91 \\
Rumen volume, liters & 60.0 & 64.2 & 56.0 & 6.43 \\
Turnover rate, liters/h & 4.1 & 4.3 & 3.8 & .4 \\
Steer weight, $\mathrm{kg}$ & 333 & 338 & 350 & \\
\hline
\end{tabular}

"Standard error of the mean, $n=3$.

rate values are typical of forage diets and similar to the $7.7 \% / \mathrm{h}$ reported by McCollum and Galyean (1984) during January 1983 at Ft. Stanton. Other studies have shown that fluid turnover and total fluid volume increase as total intake increases (Grovum and Hecker 1973). Increasing fluid dilution rate may also increase the relative proportions of acetate and butyrate while decreasing propionate (Owens and Isaacson 1977); however, this relationship may not hold over a wide variety of diets (Estell and Galyean 1985). Dilution rate in this study was unaffected by supplementation, which generally corresponds with responses observed in total VFA and individual acids, although there was an increase in total VFA and proportion of propionate at $8 \mathrm{~h}$ post-supplementation for both supplemented groups.

Table 6. Molar proportions of acetate, propionate, butyrate and total volatile fatty acids in the rumen of steers grazing blue grama rangeland receiving alfalfa pellets (ALF), cottonseed cake (CSC) or no supplemental feed $(\mathrm{CON})$.

\begin{tabular}{|c|c|c|c|c|c|}
\hline \multirow[b]{2}{*}{ Item } & \multicolumn{5}{|c|}{ Time after supplementation (b) } \\
\hline & 0 & 4 & 8 & 11 & 24 \\
\hline & & & $1 / 100 \mathrm{~m}$ & & - \\
\hline \multicolumn{6}{|l|}{ Acetate } \\
\hline ALF & 76.2 & 73.1 & $71.3^{b}$ & $70.3^{b}$ & 73.3 \\
\hline $\mathrm{CSC}$ & 77.6 & 75.1 & $73.5^{\mathrm{c}}$ & $73.4^{\mathrm{c}}$ & 74.8 \\
\hline CON & 76.4 & 76.3 & $75.9^{d}$ & $76.2^{\mathrm{d}}$ & 75.5 \\
\hline $\mathrm{SE}^{\mathrm{a}}$ & .7 & 1.5 & .6 & .7 & .8 \\
\hline \multicolumn{6}{|l|}{ Propionate } \\
\hline ALF & 17.1 & $19.1^{\mathrm{b}}$ & $20.5^{b}$ & $21.1^{b}$ & 17.8 \\
\hline $\mathrm{CSC}$ & 16.2 & $15.8^{\mathrm{c}}$ & $17.3^{\mathrm{c}}$ & $17.3^{\mathrm{c}}$ & 18.0 \\
\hline CON & 16.5 & $16.2^{\mathrm{c}}$ & $15.4^{d}$ & $15.6^{\mathrm{d}}$ & 16.8 \\
\hline$S E^{\mathrm{a}}$ & .5 & .7 & .6 & .3 & .5 \\
\hline \multicolumn{6}{|l|}{ Butyrate } \\
\hline ALF & 6.8 & 7.7 & 8.2 & 8.6 & 9.0 \\
\hline $\mathrm{CSC}$ & 6.2 & 9.1 & 9.2 & 9.3 & 7.2 \\
\hline CON & 7.1 & 7.5 & 8.7 & 8.2 & 7.6 \\
\hline$S E^{\mathfrak{a}}$ & .3 & 1.1 & .7 & .6 & .8 \\
\hline \multicolumn{6}{|l|}{ Total } \\
\hline ALF & 93.3 & 116.6 & $113.4^{b}$ & 121.3 & 109.4 \\
\hline $\mathrm{CSC}$ & 105.8 & 73.3 & $109.8^{b}$ & 123.3 & 111.6 \\
\hline $\mathrm{CON}$ & 99.6 & 94.4 & $75.9^{c}$ & 103.6 & 113.9 \\
\hline $\mathrm{SE}^{\star}$ & 10.9 & 16.8 & 7.8 & 8.9 & 7.3 \\
\hline
\end{tabular}

Standard error of the mean, $n=3$.

bed Means with different superscripts differ $(P<05)$.

Molar proportions of acetate and propionate (Table 6) differed $(P<.05)$ among supplementation groups at 8 and $11 \mathrm{~h}$ after supplementation. At $8 \mathrm{~h}$, acetate was lowest $(P<.05)$ in ALF steers $(71.3 \mathrm{~mol} / 100 \mathrm{~mol})$, intermediate in CSC steers $(73.5 \mathrm{~mol} / 100 \mathrm{~mol})$ and highest $(P<.05)$ in CON steers $(75.9 \mathrm{~mol} / 100 \mathrm{~mol})$. Propionate was highest $(P<.05)$ in ALF steers $(20.5 \mathrm{~mol} / 100 \mathrm{~mol})$, intermediate in CSC steers $(17.3 \mathrm{~mol} / 100 \mathrm{~mol})$ and lowest $(P<.05)$ in CON steers $(15.4 \mathrm{~mol} / 100 \mathrm{~mol})$. Butyrate proportions were not altered by supplementation. Total volatile fatty acid concentrations differed $(P<.05)$ only at $8 \mathrm{~h}$ after supplementation, at which time steers supplemented with ALF $(113.4 \mathrm{mM})$ and CSC $(109.8 \mathrm{mM})$ had similar total volatile fatty acid concentrations while CON steers $(75.9 \mathrm{mM})$ had lower $(P<.05)$ values.

The shift in acetate: propionate observed as a result of ALF and CSC supplementation may have an impact on energy metabolism of the grazing ruminant. Specific information on rates of production and absorption of VFA would be needed to determine the extent to which energy metabolism was influenced. Research by other workers concerning VFA concentrations as influenced by 
supplementation is not conclusive. Wagner et al. (1983) and Topps et al. (1965), working with cattle grazing dormant rangeland, reported no differences in molar proportions of acetate and propionate due to protein supplementation. McCollum and Galyean (1985), working with cottonseed meal-supplemented steers fed prairie hay, noted a shift from acetate to propionate but no difference in total VFA concentration.

The extent to which protein supplementation stimulates livestock performance and digestive processes remains uncertain in light of the current results. Ruminal escape of supplemental protein and subsequent metabolic stimulation of intake may be a factor involved in responses to protein supplementation. The current data would suggest that supplemental protein did not increase heifer weight gains through associative effects that caused increased passage rates and forage intake. Fermentation measurements indicate some stimulatory effects of protein supplements. Low rumen ammonia concentrations not consistently stimulated by supplementation coupled with low available forage protein imply that rate of ammonia production is low or that utilization and incorporation of additional ammonia into microbial protein and(or) absorption across the rumen wall is rapid. It should be noted, however, that the sampling scheme employed in this study was most likely inadequate to detect peak ammonia concentrations following supplementation, and further study is warranted. The slight shift toward propionate production may improve metabolic energy efficiency, but the exact role of shifts in VFA proportions needs clarification. It is clear, however, that further study of rumen fermentation patterns is needed to evaluate the effects of such fermentation shifts on animal metabolism and resulting performance.

Overall, it appears that protein supplementation of cattle on dormant blue grama rangeland can improve livestock performance. Fermentation shifts may, in part, be responsible for improved performance. Associative effects, while noted in other studies, were not an apparent factor with the current data. The data suggest that improved livestock performance with protein supplementation may be a result of meeting dietary requirements and not enhanced forage intake.

\section{Literature Cited}

Allden, W. G. 1981. Energy and protein supplements for grazing livestock. p. 289-307. In: F. H. W. Morley (ed.). Grazing animals. Elsevier Scientific Publ. Co., New York.

Bellido, M. M., J. D. Wallace, E. E. Parker, and M. D. Finkner. 1981. Influence of breed, calving season, supplementation and year on productivity of range cows. J. Anim. Sci. 52:455-468.

Broderick, G. A., and J. H. Kang. 1980. Automated simultaneous determination of ammonia and total amino acids in ruminal fluid and in vitro media. J. Dairy Sci. 33:64-68.

Campling, R. C. 1970. Physical regulation of voluntary intake. p. 226-234. In: A. T. Phillipson (ed.). Physiology of digestion and metabolism in the ruminant. Oriel Press, Newcastle, England.

Campling, R. C., M. Freer, and C. C. Balch. 1962. Factors affecting the voluntary intake of food by cows. III. Effect of urea on voluntary intake of oat straw. Brit. J. Nutr. 16:115-123.

Clanton, D. C. 1982. Crude protein system in range supplements. p. 228237. In: F. N. Owens (ed.). Protein requirements for beef cattle: Symposum. Oklahoma Agr. Exp. Sta. Misc. Pub. MP-109.

Egan, A. R. 1965. Nutritional status and intake regulation in sheep. II. The influence of sustained duodenal infusions of casein or urea upon voluntary intake of low protein roughage by sheep. Aust. J. Agr. Sci. Camb. 69:375-384.

Ellis, W. C. 1978. Determinants of grazed forage intake and digestibility. J. Dairy Sci. 61:1828-1840.

Estell, R.E. II, and M.L. Galyean. 1985. Relationship of rumen fluid dilution rate to rumen fermentation and dietary characteristics of beef steers. J. Anim. Sci. 60:106-1071.

Forero, O., F. N. Owens, and K. J. Lusby. 1980. Evaluation of slow-release urea for winter supplementation of lactating range cows. J. Anim. Sci. 50:532-535.

Freer, M. 1981. The control of food intake in grazing animals. p. 105-124. In:F.H.W. Morley (ed.). Grazing animals. Elsevier Scientific Publ., Co., New York.
Goetsch, A. L., and M. L. Galyean. 1983. Influence of feeding on passage of fluid and particulate markers in steers fed a concentrate diet. Can. J. Anim. Sci. 63:727-730.

Grovum, W. L., and J. F. Hecker. 1973. Rate of passage of digesta in sheep. 2. The effect of level of food intake on digesta retention times and on water and electrolyte absorption in the large intestine. Brit. J. Nutr. 30:221-230.

Grummer, R. R., J. H. Clark, C. L. Davis, and M. R. Murphy. 1984. Effect of ruminal ammonia-nitrogen concentration on protein degradation in situ. J. Dairy Sci. 67:2294-2301.

Judkins, M. B., J. D. Wallace, M. L. Galyean, and E. E. Parker. 1984. Comparison of various marker techniques for estimation of fecal output and intake in protein supplemented, grazing steers. Proc. West. Sec. Amer. Soc. Anim. Sci. 35:177-179.

Judkins, M. B., L. J. Krysl, J. D. Wallace, M. L. Galyean, K. D. Jones, and E. E. Parker. 1985. Intake and diet selection by protein supplemented grazing steers. J. Range Manage. 38:210-214.

Kellaway, R. C., and J. Leibholz. 1983. Effects of nitrogen supplements on intake and utilization of low-quality forages. World Anim. Rev. 48:33-37.

Kemptom, T. J., J. V. Nolan, and R. A. Leng. 1977. Principles for the use of nonprotein nitrogen and by-pass protein in diets for ruminants. World Anim. Rev. 22:2-7.

Kothmann, M. M. 1980. Nutrition of livestock grazing on range and pasture lands, p. 56-90. Im: D. C. Church (ed.). Digestive physiology and nutrition of ruminants (2nd ed.). $\mathrm{O}$ and B Books, Corvallis, Ore.

McCollum, F. T., and M. L. Galyean. 1985. Influence of cottonseed meal supplementation on voluntary intake, rumen fermentation and rate of passage of prairie hay in beef steers. J. Anim. Sci. 60:570-577.

Mehrez, A. Z., E. R. Orskov, and I. McDonald. 1977. Rates of rumen fermentation in relation to ammonia concentration. Brit. J. Nutr. 38:437-441.

Mertens, D. R. 1977. Dietary fiber components: Relationship to the rate and extent of ruminal digestion. Fed. Proc. 36:187-192.

Minson, D. J. 1966. The apparent retention of food in the reticulo-rumen at two levels of feeding by means of an hourly feeding technique. Brit. $J$. Nutr. 20:765-770.

Morgan, P. J. K., J. P. Pienaar, and R. A. Clark. 1976. Animal-based methods of determining herbage intake and quality under grazing conditions. Proc. Grassld. Soc. South Afr. 11:73-78.

Owens, F.N., and H.R. Isancson. 1977. Rumen microbial yields: Factors influencing synthesis and bypass. Fed. Proc. 36:198-206.

Parker, E. E., J. D. Wallace, A. B. Nelson, and R. D. Pieper. 1974. Effects of cottonseed meal supplement and age at first calving on performance of range cattle. N. Mex. State Univ, Agr. Exp. Sta. Bull. 627.

Pond, K. R., W. C. Ellis, J. H. Matis, G. T. Schelling, and L. W. Greene. 1982. Compartmental models for estimating gastro-intestinal tract fill, flow and output using pulse dose marker data. J. Anim. Sci. 56(Suppl. 1):452.

Poppi, D. P., D. J. Minson, and H. Ternouth. 1980. Studies of cattle and sheep eating leaf and stem fractions of grasses. I. The voluntary intake, digestibility and retention time in the reticulo rumen. Aust. J. Agr. Res. 32:99-108.

Rittenhouse, L. R., D. C. Clanton, and C. L. Streeter. 1970. Intake and digestibility of winter-range by cattle with and without supplements. J. Anim. Sci. 31:1215-1221.

SAS. 1982. SAS user's guide. SAS Institute, Inc. Cary, N.C.

Satter, L.D., and L.L. Slyter. 1974. Effect of ammonia concentration on rumen microbial protein production in vitro. Brit. J. Nutr. 39:199-202.

Smith, B. M., and J. C. Malechek. 1974. Behavorial responses of cows to winter climatic stress. Abstr. 27th Annu. Meet. Soc. Range Manage. Tucson, Ariz.

Smith, E. F. 1981. Growing cattle on grass. Kansas Agr. Exp. Sta. Bull. 638.

Speth, C. F., V. R. Bohman, H. Melendy, and M. A. Wae. 1962. Effect of dietary supplements on cows on a semi-desert range. J. Anim. Sci. 21:444-448.

Steele, R. G. D., and J. H. Torrie. 1980. Principles and procedures of statistics (2nd ed.). McGraw-Hill Book Co., New York.

Teeter, R. G., F. N. Owens, and T. L. Mader. 1984. Ytterbium chloride as a marker for particulate matter in the rumen. J. Anim. Sci. 58:465-473.

Topps, J. H., W. C. Reed, and R. C. Elliott. 1965. The effect of season and of supplementary feeding on the rumen contents of African cattle grazing subtropical herbage. II. $\mathrm{pH}$ values and concentrations and proportions of volatile fatty acids. J. Agr. Sci. 64:397-401. 
Troelson, J. E., and J. B. Campbell. 1968. Voluntary consumption of forage by sheep and its relation to the size and shape of particles in the digestive tract. Anim. Prod. 10:289-296.

Uden, P., D. E. Colucci, and P. J. Van Soest. 1980. Investigation of chromium, cerium and cobalt as markers in digesta rate of passage studies. J. Sci. Food Agr. 31:625-632.
Van Soest, P. J. 1982. Nutritional ecology of the ruminant. O and B Books, Corvallis, Ore.

Wagner, J. J., K. S. Lusby, and G. W. Horn. 1983. Condensed molasses solubles corn steep liquor and fermented ammoniated whey as protein sources for beef cattle grazing dormant native range. J. Anim. Sci. 57:542-552. 